\title{
Clanwilliam Living LANDSCAPE PROJECT
}

John Parkington*

'Living Landscape' is a community-based museum and schools curriculum project located in the small rural Western Cape town of Clanwilliam. Founded in 1812, and originally known as Jan Dissels Vallei, Clanwilliam was for much of the 19th century a frontier settlement, in which the politics of colonialism were played out against the magnificent backdrop of the Cederberg mountains. Now, in another era of political reorganisation, the current citizens are attempting to construct a democratic future and put aside a divided past. As in most rural Cape towns the divisions take the form of white town, coloured township and black informal settlement. Our project seeks to support these attempts at reconciliation by revealing and celebrating the history of those who were previously denied a contribution.

The objective of Living Landscape is to use the local landscape as a framework for integrating the learning process and for reconnecting particularly the descendants of indigenous people with a past from which colonialism has largely severed them. It is thus a programme that seeks to empower people by establishing an accessible archive of historical, archæological and environmental information with explicit links to a new schools curriculum and new heritage legislation.

By creating a sense of local ownership over this heritage landscape, local people will be enabled and encouraged to look after its particular cultural qualities, monitor damage and participate effectively in creating a tangible sense of custodianship. In this way, future damage or disrepair, or simply neglect to the heritage, can be minimised.

Furthermore, the concept provides an opportunity for local people to take an active interest in the evolution of various possible future landscapes for the Clanwilliam area. The current interest in community involvement that is characteristic of environmental management and development programmes in South Africa is a very real issue for the furtherance of

\footnotetext{
* Written by John Parkington but referring to a group of interested historian, archaeologists and architects in Cape Town and involved in the conceptualization of the project.
} 
148 this project. This proposal provides a framework to link social and environmental programmes to the process of creating futures that are wealth creating, job widening, and environmental sustainable.

We argue here that the creation of a landscape-oriented educational effort will lead to better articulated and more effective community involvement in the sustainable development for the region. Empowerment means granting people self respect through the processes of education, confidence building, and trust. Thus, education through active engagement in past and future landscape change is a valuable tool in the empowerment process.

This project, therefore, provides an opportunity to relate history to future via empowerment, education and the building of training schemes for landscape interpretation and environmental evaluation. These tools are vital for long term land use and natural resource management in South Africa as a whole. They also provide a basis for extending the value added by tourism to the poor rural areas where meaningful interpretative capacities are currently underdeveloped. Over the next five years we plan to build a series of structures in chosen localities in the landscape that will act as learning places, resource centres and research opportunities for rural, previously disadvantaged, people.

\section{THE CLANWILLIAM LANDSCAPE}

The Clanwilliam landscape is richly endowed with remains of past social and natural histories. In geological terms the landscape reflects the momentous events of glacial action, dramatic mountain building and the fossil record of previous life forms. In archæological terms there are many thousands of rock paintings and rock shelter sites left by hunter gatherers and herders whose culture was all but extinguished by the colonial presence. In historical terms there are buildings and other residues of farming and agriculture that document a rapidly changing social landscape. On the maps there are tantalis-ing traces, in the form of indigenous place names, of the precolonial landscape and its places. In botanical and zoological terms Clanwilliam lies in the Fynbos Biome, one of the worlds six Plant Kingdoms, and the smallest of them. The plants and animals are themselves a residue of past living communities that once included elephant, rhino and lion, some of them painted on cave walls.

We see the fossils, the rock art, the place names, the plant and animal communities, the rock record and the ruined buildings as traces of the past, reflections of what was, and practical opportunities to relearn, re-claim and re-habilitate. Histories have been denied, languages have been lost, cultural identities have been denigrated as people too became traces in a changing social landscape. The re-claiming and re-connecting can form the basis of an integrated school curriculum where the results of research into local history, archæology, architecture, botany, zoology, geology and palæontology form a resource archive.

We will use the environmental context to develop a unique architectural proposal in which a network of structures relocate in the landscape. In placing the exhibit back at the point of excavation and actual site of rock paintings, fossil remains and vegetation, a number of dialogues are encouraged. If objects are not removed from 
sites in which they are found but rather contextualised in place, or re-placed, then their display can be set off against their original condition. The immediate presentation is contrasted with a deep geographical and historical past. This rediscovery is a continuous dialogue between natural and artificial, containment and release, near and far, then and now.

Each locality will be opened with an exhibition and each display will include a text on the topic covered. The objective is to accumulate information on the traces that exist in the landscape so that teachers will have a growing set of teaching materials, classroom ideas and actual specimens for their use. The active involvement of students and faculty from a wide range of departments at the University of Cape Town (UCT) will offer practical opportunities for school pupils to get involved in the gathering of knowledge as envisaged in the new CURRICULUM 2005. It is also envisaged that archæological records of the local heritage sites will be transferred back to Clanwilliam and that pupils will be able to actively research and help conserve their local heritage, as envisaged in

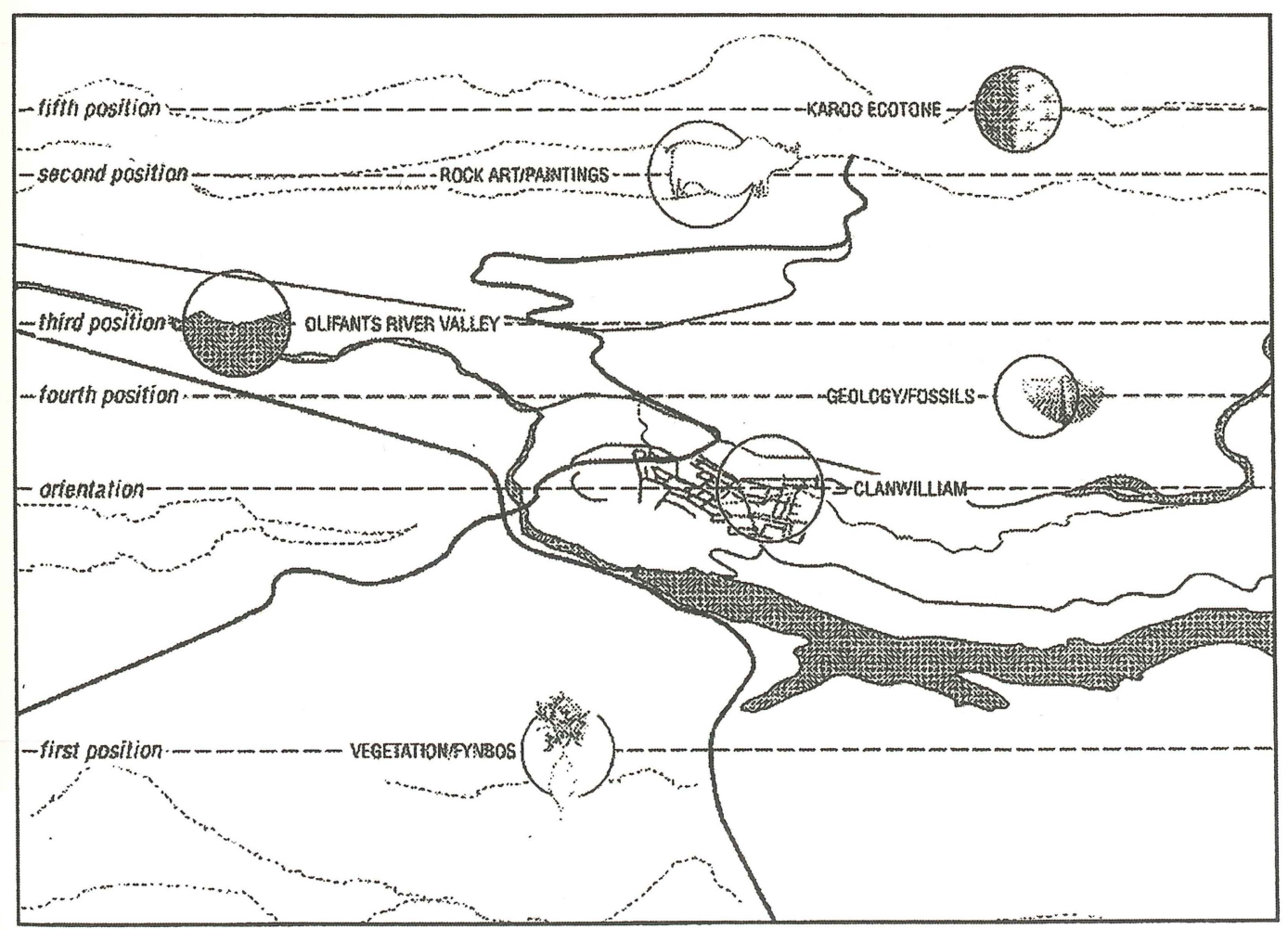

The location of exhibition and teaching structures on the Clanwilliam landscape. Each position is chosen to illustrate and explain a particular component of the Living Landscape; rock art, fossils, fynbos ecology, landscape structure. The buildings will be designed to fit the exhibits. 
150 the upcoming Heritage Legislation.

Living Landscape will establish a radically new kind of museum in which display cases and exhibition rooms are dispersed back into the landscape from which the objects and information came. The localities will each focus on one particular component of the landscape trace - rock art in a cave setting, fossil animals in a rock section, a fynbos plant community, a viewing point to understand the valley structure and will be used as extra-mural classrooms for scholars and other groups. In Clanwilliam itself we will develop an orientation locality in which records of research of all kinds will be concentrated, and in which computers will provide global access to electronic resources for young people. Noticeboards at all schools in the town will signpost and advertise the availability of resources at the other localities.

The whole museum, therefore, is completely decentralised and located with respect to the landscape at archæological and other strategic positions:

a first position for the display, dissection and illustration of fynbos vegetation; a second position for the identification of rock paintings with accompanying descriptive tracings and explanations; a third position as a lookout onto the Olifants River Valley with mapping devices;

a fourth position for fossils in a trench that descends in layers exhibiting the findings in context;

a fifth position at the edge of the Karoo ecotone with an exploration of the plant, animal and soil surrounding framework; a series of initiating positions as information boards at each school; and

an orientation position as an administrative and meeting area in .Clanwilliam.

Some of the specific proposals under the Living Landscape umbrella are the following:

\section{THE KRAKADOUW CENTRE}

In the town of Clanwilliam we propose to establish a research and resource centre which will form the focus of a UCT outreach programme, with participation from many UCT Departments. We have held a number of open meetings in Clanwilliam with a representative series of interest groups, all of which have clearly pointed to the need to address the question of how the past is represented and by whom. Currently the Clanwilliam Museum is housed in the Gaol and depicts the activities of the advantaged white community. There is an urgent need to redress this imbalance and collect histories that allow all citizens to find themselves and celebrate their past. We hope to do this alongside the establishment of a centre that situates history in its landscape context.

This centre, which we tentatively call the Krakadouw Centre will house records; maps and objects that have resulted from many years of research by a wide range of people from archæology to zoology. The proposal is to relocate the evidence to Clanwilliam and to use it as a contribution to the revised school syllabus, which calls for localisation, integration and restructuring of teaching in a research rather than a rote learning mode. It is our inten- 
tion to mount regular exhibitions of accumulated knowledge of the Clanwilliam region and its social and natural history, meshing science with humanity into one integrated study.

Our vision is of an archive which could include visual, artefactual and electronic resources that will be accessed by both pupil and teacher, regularly supported and supplied by visits from interested researchers from Cape Town. The orientation hub would thus act as a laboratory for teaching a range of practical skills, including numeracy, computer literacy, map reading, conservation awareness, resource management, survey and the collection of social and environmental information.

Funding is sought for some renovation to a small Primary School in Clanwilliam which will become the Krakadouw Centre. This school has enormous symbolic value for the coloured residents and represents all that is left of two schools and a church used by this community until sold and, partly, demolished some years ago. The buildings that stand include three classrooms, a school hall and a small cottage, these latter two much older than the classrooms and originally thatched. The hall will make an excellent exhibition and workshop space, the cottage can be turned easily into an office and computer centre and the classrooms will become accommodation for student and scholar groups.

\section{RECLAIMING LANGUAGE, KNOWLEDGE AND HISTORY}

It is a noticeable irony in Clanwilliam that most local people, with strong links to the indigenous population, never visit the museum, appear to have little interest in the local rock art, and have no control over local heritage sites. The colonial population spread rapidly through the northwestern Cape in the early 18 th century and renamed the landscape as they appropriated the land, decimated the game and turned local hunters and herders, those they did not slaughter at least, into farm labourers. As a result almost all traces of the languages, ethno-science and cultural history of indigenous people were lost or treated as insignificant. Interestingly, there are many reminders of the precolonial landscape in the form of place names that still retain their indigenous reference. In this project we map and document these traces and explore the gradual renaming of places by a succession of new comers, who recognised that to name was to claim. Several of the remaining indigenous names refer to passes or routes through the mountains, names such as krakadouw, nardouw, cardouw, kriedouwkrans or gydo, all of which retain the root dao or 'path' from the original name. Others such as tarakamma or matsikamma retain the root kamma for 'water', the former being reliably an aboriginal word for part of the Olifants River. Still others are more enigmatic, such as koekenaap, goerap or hantam. The researching of these names leads to the general issue of the reclaiming of indigenous languages, of which only Nama remains in the Western Cape.

Apart from place names the most frequent survivals of indigenous words seem to be in plant names where buchu and dacha are fully integrated into other languages. But there are many more plants that still retain their indigenous names, such as kambroo, gwhaap or canna, many 
152 of them still collected by rural communities. The research on edible and medicinal plants allows us to remember the vast store of knowledge possessed by indigenous hunter gatherers and herders, amounting to a deep understanding on their part of the active chemical ingredients of plants that had nutritional or medicinal value. There exists among the rural community of Clanwilliam an ideal opportunity to collect surviving traces of an ethno-botanical knowledge that extends back into prehistory, and is almost gone. Ironically, at the same time that this knowledge is downplayed or ignored in the local museum, international pharmaceutical companies are scouring the literature for hints as to marketable products in the local vegetation, and finding them. Given the prominence of the rooibos tea industry in the displays of the Clanwilliam Museum, this selective amnesia would be an excellent metaphor for the social injustice that needs to be addressed in the town.

What has happened during the colonial period, driven by the imbalance in literate observers and published works, is that black and brown Clanwilliam people have been written out of history. In the present displays in the Clanwilliam Museum these groups are barely reflected, and then only in supportive or silent roles. We have already started to collect oral histories from local people whose ancestors have lived on the local farms or in Clanwilliam itself for many generations. Our intention is to exhibit materials that will both broaden and lengthen the notion of history presently used in the museum. People will talk and write themselves back into history.

\section{ROCK ART IN THE LANDSCAPE}

Over the past 25 years we have located, recorded and studied about 2000 rock art sites in the Western Cape, many of them in the Clanwilliam landscape. These images, which probably number some 100000 in all, are a complex reflection of the religious and symbolic lives of the artists. Far from a simple record of animals and social activities, the paintings were a marking of the landscape with signs and reminders of appropriate social behaviour. They tell not of what people do but of what people are. They remain today as a poignant reminder of a people culturally extinct. Unfortunately the paintings are often defaced by people ignorant of their historical and symbolic value, who write their names over them or chip away at them. It is our responsibility to try to protect these traces by education, surely the best fence we can put around them.

In this project we plan to return our records of these paintings to Clanwilliam in the form of tracings, maps and electronic site information so that the archive can become accessible to local people. In addition we believe that local groups, including scholars, can develop a system of conservation by increasing local awareness of the beauty, fragiligy and vulnerability of the art. More than that, local people can act as monitors of damage by establishing a schedule of site visits that will detect damage and begin the process of reparation. What we envisage is a monitoring conservation group, based in local schools, which will assume responsibility for visiting and checking the status of rock painting sites as well as for the removal, under supervision, of any graffiti 
that appear. This will eventually be offered to all local landowners as a service and will involve local people quite practically in the conservation of landscape resources. Unless local people can be drawn into the practice of conservation, we see little chance of protecting the many thousands of rock paintings in the region. The conservation awareness can be expanded to include the geological fossils and architectural traces that are as significant as the paintings in defining the local natural and cultural heritage.

The model of locating the the responsibility for conservation in local communities is not new and promises to generate not only renewed awareness in local achievements but also jobs in a revived archæo-tourism industry. The upcoming Heritage Legislation encourages nonGovernmental Organisations concerned about heritage to get involved in identifying, proclaiming and preserving sites of communal significance. If the study and understanding of the paintings becomes part of the school curriculum, as it should, then a conservation ethic will become one of the outcomes generated. Other likely outcomes will be the abiblity to read, interpret and make maps and an understanding of the value of computer records as management tools.

The appropriate location for the tracings, slides and written records of the rock art sites is the Krakadouw Centre in Clanwilliam, where a Curator can monitor the school use of them. We also plan to build one of the museum structures at a rock art site in the field where original painted images can be viewed and explained on site. Considerable research has been undertaken in South Africa and elsewhere on the potentials and risks in exposing rock paintings to regular viewing by groups of children or interested adults. We envisage more than simply a viewing platform, and plan to develop both a set of written texts that explain how to look at the paintings, how to decode them and thus gain a better understanding of their meaning, and also a visual key that will guide the eye to specific details and begin to build a frame of reference for future viewing.

We are also very much aware that structures that must stand largely unattended in the veld must be secure and able to withstand both the natural elements and the attentions of an initially uninformed public. The structure envisaged will be a durable and flexible design that will unfold to provide vertical and horizontal surfaces. Vertical wooden screens become descriptive frameworks for maps, texts for demonstration, spatial diagrams that underpin explanations. Stone surfaces act as path and inscription. Wooden panels serve as working surfaces and stage. Elements are slid, opened, joined or unfolded as blackboards, backdrops, shelves, tables, tablets. After each visit they can be shut and enclosed for the next.

\section{CLANWILLIAM LANDSCAPE: PAST AND PRESENT}

Clanwilliam is a remarkable as well as a very beautiful landscape. Scattered across the hills and fields are dramatic remnants of past life, survivals from earlier times and traces of events hard to imagine in the present landscape. It is our conviction that these fragments are the hooks upon which to hang a curriculum that will grab the 
154 attention of local children and make learning relevant and fun. Aided by the provision of Internet facilities, teachers will be able to tap into a global encyclopæedium of knowledge to identify, explain and research a host of issues that are plainly visible in the landscape. We envisage pupils engaging in practical projects that take them out into the local veld and allow them to record, observe, manipulate and handle real research material. Some obvious opportunities are listed below.

Clanwilliam enjoys now a mediterranean-type winter rainfall climate and lies in a stable mountainous valley, with abundant water provided by the Olifants River. But buried in the local rock sequence are fossils of animals that lived in glacial lakes; on the local hillsides are the marks caused by huge glaciers; and the mountains themselves are evidence of massive faulting, slumping and warping of rock strata. At one time Clanwilliam Bay was a large embayment in an ancient sea located between the mountains now under the Atlantic Sea and those of the present Karoo region. As the nearby glaciers melted the lakes housed hundreds of now extinct forms of life that are perfectly preserved in the clays of the Clanwilliam landscape. Many millions of years later, early people ranged along the banks of the palæo-Olifants River in search of giant zebras, giant buffalo, giant hartebeest and other animals now long extinct. These sites and the evidence they hold will fuel the interest and excitement of young people and lead them inevitably to the study of palæontology, archæology and geology.

The plant communities of the Clanwilliam landscape belong to the Fynbos Biome. Famous among botanists, it has a bewildering variety of species and associations, including the Clanwilliam cedar groves, which are probably a relict from times when conditions were both wetter and colder than now. In fact the Fynbos is itself a phenomenon of persistent climatic and environmental change that saw communities repeatedly retreating to mountainous refuges as conditions became temporarily unsuitable. The Fynbos with its particular set of animal and plant associations is on the doorstep of Clanwilliam pupils and provides a natural entry point for the study of botany, zoology and environmental science. It is not hard to picture scholars collecting rainfall information, measuring the flow of the Olifants River, counting animal tracks as a way to assess numbers, helping on palæontological and archæological digs. Such involvement will engender a real and permanent sense of the value of conservation and the need for sustainable use of the local landscape. Workshops with teachers from all three Clanwilliam schools have convinced us that there is a great enthusiasm on their part to receive materials and implement new practices.

John Parkington är professor i arkeologi vid Cape Town University. Hans forskning är inriktad på hällmålningar och hällristningar.

Adr: Archaeological Department, University of Cape Town, ZA-Cape Town, South Africa

Fax: $+27-216502352$

e-mail: jep@beattie.uct.ac.za 